\title{
\begin{tabular}{l} 
TD D $D$ \\
\hline Journal of Innovation, Evaluation and Learning Development \\
\hline
\end{tabular}
}

\section{Peran Guru dalam Pembelajaran Home visit di Masa Pandemi Covid-19 pada Siswa Sekolah Dasar}

\author{
Jama'ah \\ Program studi Pendidikan Sejarah, STKIP Yapis Dompu \\ E-mail: jamaah.daha@gmail.com
}

Article History: Received: 2021-08-16 || Revised: 2021-08-20 || Published: 2021-08-20

Sejarah Artikel : Diterima: 2021-08-16 || Direvisi: 2021-08-20 || Dipublikasi: 2021-08-20

\begin{abstract}
This research is a qualitative research with a phenomenological approach and tehe data sources are obtained from primary data and secondary data related to the implementation of home visit learning at SD Negeri 25 Woja. The instruments in this study were observation guidelines, interview guidelines and documentation guidelines. Data collection tecniques were obtained from observation, interviews, and documentation. Data analysis techniques include data collection, data reduction, data presentation, and drawing conclusions and verification. Checking the validity of the findings obtained from triangulation of sources and triangulation of tecniques. The results showed that SD Negeri 25 Woja carried out face to face learning based on the Circules of the Regent of Dompu: Number 420/3495.UM/Dikbud dated July 22, 2020 regarding the implementation of face to face learning in the green and yellow zones during the Covid-19 pandemic (Spesial condition). As for the implementation of the home visit, there are three stages, namely: a) the preparation stage, b) the implementation stage, divided into 2, namely: the implementation stage of the initial activities and follow-up activities, e) the monitoring and evalution stage of learning. This research can be concluded that: 1) learning this home visit was carried out based on the instruction of the Dompu Regent Circuler: Number 420/3495.UM/Dikbud dated July 22, 2020 regarding the implementation of face to face learning in thr green and yellow zones during the Covid-19 pandemic (Spesial conditions), 2) the implementation of home visits contained three stages, namely: a) the preparation stage b) the implementation stage is divided into two, namely: the initial activity implementation stage and the implementation stage of the follow-up activities, e) the monitoring and evaluation stage of learning.
\end{abstract}

Keywords: Teacher's Role, Home Visit, Pandemic, Covid-19.

\begin{abstract}
Abstrak
Penelitian ini merupakan penelitian kualitatif dengan pendekatan fenomenologi dan sumber data diperoleh dari data primer dan data sekunder yang berkaitan dengan pelaksanaan pembelajaran home visit di SD Negeri 25 Woja. Instrumen dalam penelitian ini berupa pedoman observasi, pedoman wawancara dan pedoman dokumentasi. Teknik pengumpulan data diperoleh dari observasi, wawancara, dan dokumentasi. Teknik analisis data berupa pengumpulan data, reduksi data, penyajian data, dan penarikan kesimpulan dan verifikasi. Pengecekan keabsahan temuan di peroleh dari triangulasi sumber dan triangulasi teknik. Hasil penelitian menunjukkan bahwa SD Negeri 25 Woja melaksanakan pembelajaran tatap muka berdasarkan Surat Edaran Bupati Dompu: Nomor 420/3495.UM/Dikbud tanggal 22 Juli 2020 tentang penyelenggaraan pembelajaran tatap muka pada zona hijau dan kuning di masa pandemi Covid-19 (kondisi khusus). Adapun pada pengimplementasian home visit terdapat tiga tahapan yaitu: a) tahap persiapan, b) tahap pelaksanaan, dibagi menjadi 2 yaitu: tahap pelaksanaan kegiatan awal dan kegiatan lanjutan, c) tahap monitoring dan evaluasi pembelajaran, Penelitian ini dapat disimpulkan bahwa: 1) pembelajaran home visit ini dilakukan berdasarkan instruksi Surat Edaran Bupati Dompu: Nomor 420/3495.UM/Dikbud tanggal 22 Juli 2020 tentang penyelenggaraan pembelajaran tatap muka pada zona hijau dan kuning di masa pandemi Covid-19 (kondisi khusus). 2) pelaksanaan home visit terdapat tiga tahap yaitu: a) tahap persiapan b) tahap pelaksanaan terbagi menjai dua yaitu: tahap pelaksanaan kegiatan awal dan tahap pelaksanaan kegiatan lanjutan. c) tahap monitoring dan evaluasi pembelajaran.
\end{abstract}

Kata kunci: Peran Guru, Kunjungan dirumah, Pandemi, Covid-19.

\section{PENDAhUluan}

Peranan guru sangat penting dalam proses pembelajaran, serta memajukan dunia pendidikan. Kualitas peserta didik dalam dunia pendidikan sangat bergantung pada mutu guru. Karena itu guru 
harus memiliki kompetensi yang sesuai dengan Standar Nasional Pendidikan agar dapat menjalankan tugas dan perannya dengan standard kompetensi yang baik yang menghasilkan peserta didik menjadi manusia yang berilmu dan memiliki keterampilan-keterampilan tertentu, Pendidikan adalah usaha sadar untuk menyiapkan peserta didik melalui kegiatan bimbingan, pengajaran dan latihan-latihan untuk mempersiapkan kehidupan yang lebih baik dimasa yang akan dating, Orang tua mempercayakan sekolah sebagai suatu lembaga pendidikan untuk mendidik anak-anaknya memiliki keterampilan, kecerdasan, sebagaimana yang dinyatakan oleh Jejen Musfah dalam bukunya peningkatan kompetensi guru bahwa "Guru harus dapat merancang pembelajaran yang tidak semata menyentuh aspek kognitif, tetapi juga dapat mengembangkan keterampilan dan sikap siswa, Maka guru haruslah individu yang kaya pengalaman dan mampu mentransformasikan pengalamannya itu pada para siswa dengan cara-cara yang variatif" Jejen Musfah, (dalam Sumiati, 2018: 148).

Manusia sudah memiliki potensi untuk belajar, maka sebagai guru harus menguasai materi pelajaran, menyampaikan pengajaran dengan tepat, dan menangani permasalahan murid dengan tepat pula, atau dengan perkataan lain guru harus cerdas dan terampil dalam kegiatan pembelajaran, Guru harus mempunyai kompetensi dalam mendidik sehingga akan menghasilkan anak didik yang berkualitas, maka kompetensi yang harus dimiliki guru adalah kompetensi pedagogis yaitu seperangkat kemampuan dan keterampilan (Skill) yang berkaitan dengan interaksi pembelajaran antara guru dan peserta didik dalam kelas, yang meliputi kemampuan guru dalam menjelaskan materi, melaksanakan metode pembelajaran, memberikan pertanyaan, menjawab pertanyaan, mengelola kelas, dan melaksanakan evaluasi, seorang guru menjadi pendidik berarti sekaligus menjadi pembimbing. Sebagai contoh guru yang berfungsi sebagai pendidik dan pengajar seringkali akan melakukan pekerjaan bimbingan, misalnya bimbingan belajar, bimbingan tentang keterampilan dan sebagainya. Jadi yang jelas dalam proses pendidikan kegiatan mendidik, mengajar, dan bimbingan sebagai suatu hal yang tidak dapat dipisah-pisahkan. Sardiman, (dalam Ahmad Idzhar, 2016: 223).

Seorang guru harus mampu mendemonstrasikan kemampuannya di depan siswa dan menunjukkan sikap-sikap terpuji dalam setiap aspek kehidupan. Guru merupakan sosok ideal bagi setiap siswa. Biasanya apa yang dilakukan guru akan menjadi acuan bagi siswa. Dengan demikian guru sebagai model bagi siswa, maka semua gerak langkahnya akan menjadi teladan bagi setiap siswa. Istarani, (dalam Hendra, 2017: 22), Pasca pandemi Covid-19 masuk ke Indonesia yang kemudian pertengahan Maret 2020 untuk menekan angka penderita Covid-19, pemerintah Provinsi dan pemerintah daerah menghasilkan kebijakan dalam dunia pendidikan. Mengingat adanya perkembangan pandemi Covid-19 dan ditambah lagi keterbatasan waktu dalam proses belajar dan mengajar disekolah, sehingga SD Negeri 25 Woja, menerapkan kebijakan untuk meniadakan sementara pembelajaran tatap muka di sekolah dan diganti dengan sistem pembelajaran homevisit (kunjungan rumah) sesuai dengan Surat Edaran Bupati Dompu Nomor 420/3320/.UM/Dikbud tanggal 22 Juli 2020 selama pandemi Covid-19.

Kunjungan rumah atau home visit adalah salah satu jenis kegiatan pendukung layanan bimbingan yang dilakukan oleh pendidik dalam rangka mengumpulkan dan melengkapi data atau informasi tentang peserta didik, dengan cara mengujungi rumah peserta didik sebagai alternatif pembelajaran selama pandemi Covid-19, Menurut Akhmad Sudrajat, (dalam Husna Amalia, 2016: 80). Dalam kegiatan ini guru berperan sebagai pembimbing para siswa untuk dapat lebih mengembangkan dirinya. Bimbingan yang dilakukan oleh guru tidak hanya bagi siswa yang bermasalah tapi juga pada semua siswa, agar tiap anak terdorong motivasi belajarnya sehingga dapat berprestasi dengan baik, Kata home visit berasal dari bahasa inggris, home artinya rumah, dan visit artinya mengunjungi. Home visit merupakan salah satu metode dalam menjembatangi komunikasi antara sekolah dengan orang tua peserta didik dan masyarakat. Adanya home visit membantu sekolah dalam menyelesaikan berbagai masalah yang berkaitan dengan peserta didik sangat penting sekali bagi sekolah dalam rangka mengatasi berbagai masalah yang terjadi antara sekolah dengan peserta didik. Yaqien, (dalam Ade Irma Anggraeni, 2018: 2)

Berdasarkan hasil observasi awal pada tanggal 24 Agustus 2020 yang telah dilakukan peneliti mendapatkan setidaknya gambaran bahwa selama Covid-19 pemerintah mengharuskan untuk belajar dirumah sehingga SD Negeri 25 Woja menerapkan pembelajaran home visit pada masa 
pandemi Covid-19, Fakta diatas menunjukkan bahwa selama pandemi Covid-19 harus ada penyesuaian cara belajar dalam proses pembelajaran di SD Negeri 25 Woja. Dalam ranah struktural sekolah, guru harus bekerja sama dengan orang tua siswa agar proses pembelajaran home visit berjalan dengan baik. Maka dalam hal ini peneliti ingin melakukan penelitian tentang "Peran guru dalam pembelajaran home visit di masa pandemi pada siswa kelas IV di SD Negeri 25 Woja Tahun Pembelajaran 2020/2021".

\section{METODE PENELITIAN}

Penelitian ini adalah metode penelitian kualitatif dengan pendekatan fenomenologi, pendekatan fenomenologi bertujuan untuk menggambarkan makna dari pengalaman yang dialami oleh beberapa siswa mengenai pembelajaran home visit, Kehadiran peneliti di lapangan untuk penelitian kualitatif mutlak diperlukan. Peran peneliti dalam penelitian ini sebagai pengamat partisipasi atau pengamat penuh. Kehadiran peneliti juga diketahui oleh informan atau lembaga yang diteliti. (Ahmad Tanzeh, 2011: 167), Dalam mengumpulkan data dalam penelitian ini maka penulis menggunakan metode yaitu: Observasi, wawancara dan dokumentasi dilakukan di SD Negeri 25 Woja metode ini digunakan untuk memperoleh data mengenai peran guru dalam pembelajaran home visit di masa pandemi Covid-19 pada siswa kelas IV SD Negeri 25 Woja, Teknik analisis data dalam penelitian ini yaitu: pengumpulan data (Data Collection), mereduksi data (data reduction), penyajian data (data display), dan penarikan simpulan dan verifikasi (Conslusion drawing/verifying), Pengecekan keabsahan temuan dalam penelitian ini yaitu: triangulasi sumber dan triangulasi teknk. Serta terdapat tahap-tahap penelitian dalam penelitian yaitu: tahap perencanaan, tahap pelaksanaan dan tahap penyajian.

\section{HASIL DAN PEMBAHASAN}

\section{A. Hasil Penelitian}

1) Data hasil Observasi

Pada saat pelaksanaan pembelajaran home visit di masa pandemi Covid-19 dapat dilihat dari langkah-langkah pembelajaranya, guru pada saat proses pembelajaran berlangsung melalui teknik observasi, Berdasarkan hasil pengamatan, guru telah melakukan kunjungan rumah untuk proses pembelajaran home visit, terlihat dari aspek observasi guru menyediakan rangkuman yang berupa tugas yang diambil dari buku paket yang sesuai dengan Tema yang akan disampaikan kepada siswa pada saat proses pembelajaran, selanjutnya guru membagi siswa dalam bentuk kelompok belajar, terlihat guru juga menyuruh siswa untuk mencuci tangan, memakai masker dan menjaga jarak pada saat pembelajaran home visit, kemudian guru menyusun skenario pembelajaran sesuai dengan materi pembelajaran, terlihat juga guru melakukan apresiasi yang sesuai dengan kompetensi yang akan dicapai, Kemudian guru memantau kemajuan siswa dalam mengerjakan tugas, setelah itu guru memberikan pengayaantindak lanjut kepada siswa, selanjutnya guru memberikan latihan kepada siswaselain itu, guru melaksanakan evaluasi akhir sesuai dengan kompetensi siswa. (O/G/06.03/2021).

2) Data hasil Wawancara

a) Data hasil wawancara kepala sekolah

Sekolah SD Negeri 25 Woja dalam penerapan pembelajaran home visit di masa pandemi Covid-19 dilakukan sebagai upaya mengoptimalkan proses belajar mengajar di masa pandemi Covid-19 agar menghindari kerumunan. Hal tersebut sesuai dengan hasil wawancara dengan Ibu M selaku kepala sekolah SD Negeri 25 Woja, yang menyatakan bahwa:

"Pelaksanaan pembelajaran tatap muka dilarang berkumpul karena adanya Covid-19 sehingga sekolah memutuskan untuk belajar dirumah selama Covid-19" (WCR/KPS/M/06.03/2021)

Mengingat adanya perkembangan pandemi Covid-19 dan ditambah lagi keterbatasan waktu dalam proses belajar mengajar di sekolah, sehingga SD Negeri 25 Woja menerapkan kebijakan untuk meniadakan sementara pembelajaran tatap muka di sekolah dan diganti dengan sistem pembelajaran home visit (kunjungan rumah). Hal tersebut sesuai dengan hasil wawancara dengan Ibu M selaku kepala sekolah SD Negeri 25 Woja, yang menyatakan bahwa: 
"Sekolah menerapkan kebijakan untuk meniadakan sementara pembelajaran tatap muka dan diganti dengan pembelajaran kunjungan rumah" (WCR/KPS/M/06.03/2021)

Pembelajaran berkunjung ke rumah dilakukan dengan cara guru mengunjungi rumah peserta didik untuk memberikan tugas yang harus dikerjakan oleh siswa dan bagi siswa yang tidak hadir dalam pertemuan tersebut guru akan menitipkan kepada teman-temanya. Hal tersebut sesuai yang dikatakan oleh Ibu M pada hasil wawancara yaitu:

"Pembelajaran yang dilakukan dengan memberikan tugas dengan cara kami berkunjung ke rumah siswa dan kalau siswa tidak hadir dalam pertemuan tersebut kami menitipkan tugas kepada teman-temannya" (WCR/KPS/M/06.03/2021)

Berdasarkan data yang telah dipaparkan, dapat disimpulkan SD Negeri 25 Woja melaksanakan pembelajaran sesuai dengan kebijakan pemerintah di mana pada awal masa pandemi Covid-19SD Negeri 25 Woja menerapkan pembelajaran home visit agar dapat menghindari kerumunan dengan sistem pemberian tugas. Melalui pembelajaran home visit pada kelompok belajar akan mempermudah guru dalam membimbing dalam kegiatan belajar peserta didik dan lebih terfokus dalam membimbing perserta didik dalam proses pembelajaran.

b) Data hasil wawancara guru

Dari hasil wawancara dengan guru Kelas IV dalam proses pembelajaran home visit di masa pandemi Covid-19, guru telah mempersiapkan Silabus, RPP, Buku Paket dan Rangkuman Tugas Latihan yang sesuai materi untuk menunjang proses pembelajaran dan agar tujuan pembelajaran menjadi lebih terarah.

"Sebelum memulai proses pembelajaran biasanya saya menyediahkan perangkat-perangkat pembelajaran seperti Silabus, RPP dan Rangkuman Tugas Latihan yang sesuai dengan materi yang akan diajarkan dengan tujuan untuk menunjang proses pembelajaran." (WCR/G/06.03 /2021).

"Media pembelajaran sangat penting untuk membantu tersampainnya materi pembelajaran dengan baik, media yang saya gunakan ketika menyampaikan materi pembelajaran home visit itu berupa buku paket dan rangkuman pembelajaran yang telah dirangkum sesuai dengan tema dan subtema yang berkaitan dengan pembelajaran." (WCR /G/06.03/2021).

Pada saat menjelaskan materi pembelajaran home visit di masa pandemi Covid-19 guru menggunakan pendekatan saintifik dengan metode simulasi, diskusi, Tanya jawab,penugasan dan ceramah.

"Lebih senang menggunakan metode ini, dan sangat cocok untuk pembelajaran home visit di masa pandemi Covid-19." (WCR /G/06.03/2021)

Wawancara selanjutnya terkait dengan respon siswa selama mengikuti pembelajaran home visit di masa pandemi Covid-19.

"Respon siswa bagus, pembelajaran menjadi menyenangkan, siswa aktif dan rajin mengerjakan tugas latihan yang diberikan selama pandemi Covid-19." (WCR/G/06.03/2021)

"Penerapan pembelajaran home visit berjalan dengan baik selama masa pandemi Covid-19 yang diterapkan di rumah siswa masing-masing, karena siswa merasa termotivasi dalam mengerjakan tugas latihan. Guru mengatakan saya senang melihat perubahan dari siswa. Guru berharap agar siswa tidak bosan untuk mengerjakan tugas walaupun adanya perubahan tempat belajar karena adanya pandemi Covid-19." (WCR/G/06.03/2021)

Dari penjelasan di atas dapat disimpulkan bahwa pada saat proses pembelajaran home visit di masa pandemi Covid-19 sangat penting bagi guru untuk menyiapkan perangkat-perangkat pembelajaran seperti Silabus, Rencana Pelaksanaan Pembelajaran (RPP), dan media pembelajaran yang sesuai untuk menunjang proses pembelajaran dan agar tujuan pembelajaran menjadi lebih terarah, serta guru juga menggunakan pendekatan pembelajaran yang ada di RPP. Guru juga menggunakan pembelajaran home visit dan respon siswa sangat bagus karena siswa antusias dalam mengerjakan tugas latihan yang diberikan oleh guru selama masa pandemi Covid-19. 
c) Data Hasil Wawancara Siswa

Dari hasil wawancara siswa, pada saat proses pembelajaran home visit berlangsung terdapat masalah kesulitan dalam mengerjakan tugas latihan adalah sebagai berikut:

"Kesulitan yang saya alami pada pembelajaran home visit itu sulit mengerjakan tugas latihan yang di berikan oleh pendidik."(W/S/E/04.04/2021)

Sedangkan dari konteks masalah siswa pada saat proses pembelajaran berlangsung dari hasil wawancara siswa adalah sebagai berikut:

"Jika saya belum memahami pelajaran yang disampaikan oleh guru pada saat pembelajaran home visit, saya akan bertanya kepada teman atau orang tua." (W/S/N/04.04/2021)

Sedangkan sumber hasil wawancara dengan beberapa siswa seperti IH,N, dan E kelas IV terkait dengan pembelajaran home visit adalah sebagai berikut:

"Saya senang sekali belajar di rumah walaupun tempat belajarnya berbeda, karena saya bisa menanyakan langsung kepada kedua orang tua mengenai kesulitan tugas yang diberikan oleh guru." (WCR/S/IH/04.04/2021)

"Sangat senang sekali karena dengan adanya pembelajaran home visit dapat membuat saya semangat dalam belajar walaupun tempatnya berbeda" (WCR/S/IH/04.04/2021)

"Saya merasa malas karena banyaknya tugas yang diberikan dan juga merasa senang karena guru selalu datang kerumah untuk menyampaikan materi pembelajaran selama masa pandemi Covid-19" (WCR/S/IH/04.04/2021)

Dari data tersebut dapat disimpulkan bahwa pembelajaran home visit di masa pandemi Covid19 di kelas IV dapat berjalan dengan baik, ketika siswa mengalami kesulitan dalam pembelajaran home visit siswa akan bertanya kepada teman atau kedua orang tuanya, proses pembelajaran home visit sangat diterima dengan baik oleh siswa dan kedua orang tua.

d) Data Hasil Wawancara Orang Tua

Dari hasil wawancara dengan orang tua siswa pada saat proses pembelajaran kunjungan rumah berlangsung terdapat kendala dimana ada siswa yang tidak hadir dalam pertemuan sehingga guru menitipkan tugas tersebut kepada teman-temanya. Hal ini sesuai dengan hasil wawancara dengan Ibu M sebagai berikut:

"siswa tidak hadir dalam pembelajaran kunjungan rumah maka guru akan menitipkan materi pelajaran kepada teman atau kedua orang tua" (W/OTS/M/04.04/2021)

Orang tua akan membantu anak-anaknya ketika tidak bisa dalam mengerjakan tugas yang diberikan oleh pendidik saat menyampaikan materi pembelajaran selama di rumah hal ini sesuai dengan hasil wawancara dengan Ibu R yaitu:

"orang tua akan bertanya kembali kepada guru mengenai materi yang sulit dipahami oleh anak-anaknya" (W/OTS/R/04.04/2021)

Sedangkan sumber hasil wawancara dengan beberapa orang tua siswa seperti M, R, M terkait dengan pembelajaran kunjungan rumah (home visit) adalah sebagai berikut:

"orang tua sangat mendukung dengan adanya pembelajaran kunjungan rumah walaupun 2 kali pertemuan dalam seminggu selama masa pandemi Covid-19" (W/OTS/M/04.04/2021)

"orang tua akan memberikan arahan atau nasehat kepada anak-anaknya yang tidak mengikuti pembelajaran kunjungan rumah selama masa pandemi Covid-19" (W/OTS/M/04.04/2021)

"orang tua akan memberikan hadiah kepada anak-anaknya yang selalu rajin dalam mengerjakan tugas latihan dan juga akan memberikan hukuman kepada anak yang tidak mengerjakan tugas tersebut selama masa pandemi Covid-19" (W/OTS/M/04.04/2021)

"orang tua berharap kepada guru yang ada di SD Negeri 25 Woja agar selalu semangat dan sabar dalam mendidik anak-anak kami dalam menyampaikan materi pembelajaran selama masa pandemi Covid-19" (W/OTS/M/04.04/2021)

Dari data tersebut dapat disimpulkan bahwa pembelajaran home visit di masa pandemi Covid19 dapat diterima dengan baik oleh kedua orang tua siswa dan sangat mendukung proses 
pembelajaran kunjungan rumah walaupun 2 kali dalam seminggu, ketika siswa tidak mau mengikuti pembelajaran orang tua akan memberikan nasehat kepada anak-anaknya agar rajin dalam mengikuti serta mengerjakan tugas yang diberikan oleh guru selama pandemi Covid-19, proses pembelajaran home visit dapat diterima sangat baik oleh kedua orang siswa.

3) Data Dokumentasi

Hasil dokumentasi dilihat dari RPP yang dirancang oleh guru kelas IV pada pembelajaran home visit di masa pandemi Covid-19 adalah sebagai berikut:

"Berdasarkan hasil analisa RPP yang telah dirancang oleh guru kelas IV, bahwa guru mencatumkan pembelajaran kunjungan rumah sebagai media pembelajaran dalam RPP dengan alokasi waktu pembelajaran 1 hari (1 kali pertemuan), dan guru tersebut menggunakan media berupa buku paket dalam pembelajaran kunjungan rumah" (DOK/RPP/06.03/2021)

Guru memberikan tugas kepada siswa untuk mengetahui seberapa paham siswa dalam mengerjakan tugas dalam pembelajaran home visit adalah sebagai berikut:

"Guru senang siswa dapat menerima adanya pembelajaran kunjungan rumah (home visit)" (DOK/G/06.03/2021)

Sedangkan siswa merasa termotivasi untuk belajar dengan adanya pembelajaran kunjungan rumah.

"Siswa merasa senang dengan adanya pembelajaran kunjungan rumah (home visit)" (DOK/S/04.04/2021)

Dari data diatas dapat disimpulkan bahwa pembelajaran kunjungan rumah (home visit) sudah sangat diterima baik oleh siswa walaupun tempat belajarnya di rumah, dilihat dari antusias siswa dalam mengerjakan tugas yang diberikan oleh guru selama masa pandemi Covid-19.

\section{B. Pembahasan}

1) Pembelajaran secara Home Visit

SD Negeri 25 Woja memilih menggunakan pembelajaran luring karena memperhatikan kendalakendala pelaksanaan pembelajaran secara daring. Kendala lain yang muncul tidak hanya kesulitan dalam penerapan pembelajaran daring, namun juga terkendala dari fasilitas pembelajaran secara daring. Banyak dari peserta didik yang tidak memiliki Smartphone dan mengigat banyak peserta didik yang berasal dari ekonomi menengah kebawah tidak memungkinkan untuk melaksanakan pembelajaran tersebut sehingga SD Negeri 25 Woja menerapkan pembelajaran home visit dimasa pandemi Covid-19, Memperhatikan kurang efektifnya pembelajaran dengan sistem pemberian tugas tersebut, pada awal semester ganjil tahun ajaran 2020/2021 SD Negeri 25 Woja melakukan pembelajaran luring secara tatap muka yang dilaksanakan setelah diberlakukan new normal dan telah memperoleh Surat Edara Bupati Dompu Nomor 420/3320/.UM/Dikbud tanggal 22 Juli 2020 selama pandemi Covid-19 (kondisi khusus), Beberapa alternatif pembelajaran tatap muka di masa pandemi Covid-19. Dapat dipilih salah satu yaitu menggunakan kunjungan rumah (home visit), Ibu R memilih menggunakan home visit agar peserta didik memperoleh pembelajaran secara maksimal sehingga diharapkan dengan menggunakan home visit peserta didik mencapai kompetensi pembelajaran.

2) Tahap Pelaksanaan Pembelajaran secara Home Visit

Berdasarkan hasil observasi, wawancara, dan dokumentasi. Diperoleh data terkait implementasi pembelajaran home visit di kelas IV SD Negeri 25 Woja dengan 3 tahapan yaitu tahap persiapan Pertama, adalah pelaksanaan, tahapan evaluasi sebagai berikut:

Pada tahap persiapan, sebelum guru melaksanakan pembelajaran home visit, ada beberapa hal yang harus dilakukan yaitu: Pertama, guru mengelompokkan peserta didik menjadi beberapa kelompok belajar berdasarkan tempat tinggal, dimana pengelompokkan dilakukan dengan mengelompokkan peserta didik yang rumahnya berdekatan untuk mempermudah guru dalam melakukan home visit. peserta didik kelas IV SD Negeri 25 Woja berjumlah 32 orang siswa yang dibagi menjadi 6 kelompok belajar. Yaitu kelompok A (Woro utara) berjumlah 5 orang siswa, kelompok B (Woro selatan) berjumlah 6 orang siswa, kelompok C (Pasar wodi) berjumlah 5 
orang siswa, kelompok D (Mpuri indah) berjumlah 6 orang siswa, kelompok E (Rasana'e Utara) berjumlah 5 orang siswa, kelompok F (Bolo baka) berjumlah 5 orang siswa.

Kedua, guru membuat jadwal kunjungan rumah untuk setiap kelompok belajar peserta didik. Setiap kelompok memperoleh kunjungan dari guru sebanyak dua kali dalam seminggu. Dimana dalam satu hari guru mengunjungi dua kelompok belajar yang dilakukan secara bergantian dari satu kelompok belajar ke kelompok belajar yang lain.Adapun pembagian jadwalnya yaitu kelompok A (Woro utara) memperoleh kunjungan pada hari senin dan kamis pukul 08.00-09.30, sedangkan kelompok B (Woro selatan) memperoleh kunjungan pada hari senin dan kamis pukul 10.00-11.30, kelompok C (Pasar wodi) memperoleh kunjungan padaselasa dan jum'at pukul 08.30-09.30, kelompok D (Mpuri indah) memperoleh kunjungan pada hari selasa dan jum'at pukul 10.00-11.30, kelompok E (Rasana'e Utara) memperoleh kunjungan pada hari rabu dan sabtu pukul 08.00-09.30, kelompok F (Bolo baka) memperoleh kunjungan pada hari rabu dan sabtu pukul 10.00-11.30.

Ketiga, guru mengunjungi rumah peserta didik bahwasanya akan dilakukan kunjungan rumah dan mengkonfirmasikan apakah orang tua peserta didik setuju dengan kegiatan ini. Setelah memperoleh persetujuan dari orang tua peserta didik, guru mengkonfirmasi mengenai perlengkapan yang harus dipersiapkan pada saat pelaksanaan, dimana pada saat pembelajaran guru dan peserta didik harus menggunakan masker dan menyiapkan tempat cuci tangan dan tetap menjalankan protokol kesehatan.

Keempat, guru memberitahu orang tua siswa terlebih dahulu mengenai materi, tempat dan waktu kegiatan home visit akan dilakukan. Pelaksanaan home visit akan dilakukan kunjungan secara bergantian pada setiap rumah peserta didik dalam satu kelompok yang dilakukan agar anak memperoleh suasana belajar yang baru. Hal tersebut sesuai dengan temuan peneliti pada observasi yang dilakukan pada jadwal kunjungan yang kedua tempat kunjungan pada kelompok belajar bergantian ke rumah peserta didik yang lain dari kunjungan sebelumnya.

Setelah melakukan perencanaan pelaksanaan home visit pada tahap persiapan, selanjutnya adalah pelaksanaan atau pengimplementasian pembelajaran menggunakan home visit. Tahap pelaksanaan dibagi menjadi 2 tahap yaitu tahap pelaksanaan kegiatan awal dan tahap pelaksanaan kegiatan lanjutan. Dimana pembelajaran dari rumah dilakukan dengan waktu sekolah dipercepat dengan tetap menerapkan protokol kesehatan, anak dan guru menggunakan masker, dan memperbaharui kunjungan rumah (home visit) oleh guru agar mengoptimalkan pembelajaran (Rachman, 2020 :81-82). Pada tahap pelaksanaan awal kegiatan, guru kelas IV SD Negeri 25 Woja melakukan kunjungan kerumah peserta didik yang sudah ditentukan sebelumnya, waktu kunjungan pertama dilakukan pukul 08.00-09.30, kunjungan kedua pukul 10.00-11.30.

Pada saat pelaksanaan pembelajaran menggunakan home visit terlihat guru dan peserta didik menggunakan masker sebelum dan sesudah pelaksanaan kegiatan pembelajaran. Kegiatan ini dilakukan secara semi formal. Dimana peserta didik tidak menggunakan seragam sekolah, adapun pakaian yang digunakan adalah pakaian sehari-hari yang sopan, Kegiatan home visit ini sangat bagus digunakan di masa pandemi Covid-19 saat ini sebagai bentuk kegiatan belajar di rumah, melalui kegiatan home visitguru dapat mengawasi, melihat, dan mengawasi secara langsung kegiatan belajar peserta didik selama masa pandemi Covid-19, Melalui kegiatan ini juga, peserta didik lebih aktif dan mendapat perhatian secara menyeluruh, mengingat jumlah peserta didik yang hanya sedikit dalam setiap kelompoknya, pada saat pembelajaran siswa juga terlihat sangat semangat karena guru tidak hanya memberitahu mengenai konsep-konsep, namun juga guru mengajak siswa untuk menemukan konsep tersebut melalui pertanyaanpertanyaan yang harus dijawab oleh peserta didik. Pelaksanaan home visit dapat menjadi alternatif dalam memantau perkembangan anak selama di rumah sehingga kegiatan anak dan peran orang tua dalam membimbing anak selama belajar di rumah bisa tercapai (K. Nahdiet al, 2020 : 181).

Melalui kegiatan home visit juga, guru dapat lebih dekat dengan orang tua peserta didik dan dapat mengkonsultasikan mengenai permasalahan, kesulitan dan bakat-bakat yang dimiliki anak. Dengan melihat kegiatan pembelajaran, orang tua juga dapat mengetahui bagaimana 
anaknya belajar dan bagaimana cara guru mengajar. Sebagaimana yang telah disebutkan Nirmala dan Annur (2021:1054) Kegiatan home visit dilakukan sebagai sarana untuk menginformasikan kepada orang tua mengenai usaha yang harus dilakukan orang tua dalam mendukung pengembangan potensi, minat, dan bakat peserta didik selama di rumah. Selanjutnya setelah peserta didik memperoleh kunjungan, tahap kegiatan lanjutan dengan memberikan tugas, peserta didik memiliki tugas yang harus dikerjakan dan dikumpulkan pada kunjungan berikutnya, disini guru akan memberikan informasi kepada orang tua siswa melalui kunjungan rumah tentang tugas apa saja yang harus dikerjakan siswa dan memberikan pedoman kepada orang tua dalam membantu anaknya mengerjakan tugas.

Setelah pelaksanaan home visit, guru melakukan tahap mengevaluasi untuk mengawasi kegiatan kegiatan belajar anak diluar waktu kunjungan, pada tahap mengevaluasi ini guru mengawasi dan memantau kegiatan anak dalam belajar dirumah melalui kunjungan rumah, disini guru akan meminta orang tua untuk mengawasi selama kegiatan anak belajar di rumah, mengerjakan tugas-tugas yang telah diberikan oleh guru pada waktu kunjungan, pada kegiatan mengevaluasi ini orang tua peserta didik boleh bertanya mengenai kendala yang ditemui dalam membantu anak menyelesaikan tugas yang diberikan oleh guru, Home visit ini memiliki kelebihan dan kekurangan, kelebihannya adalah melalui home visit, pembelajaran di masa pandemi lebih efektif dan termonitoring, dikarenakan guru yang menyampaikan materi pembelajaran secara langsung. Sebagaimana disebutkan oleh K. Nahdiet al (2020 :181), pelaksanaan home visit dapat menjadi alternatif dalam memonitoring perkembangan anak selama di rumah sehingga kegiatan anak dan peran orang tua dalam membimbing anak selama belajar di rumah dapat tercapai.

Peserta didik menjadi lebih aktif dikarenakan pembelajaran dilakukan secara berkelompok dalam jumlah peserta didik yang sedikit sehingga guru lebih mudah mengawasi dan terfokus pada setiap individu peserta didik dalam kelompok, guru dapat menggali informasi lebih lanjut mengenai peserta didik melalui komunikasi dengan orang tua, sebagaimana disebutkan oleh Nirmaladan Annur, (2020:1058) Guru melakukan strategi home visit untuk menjalin komunikasi yang lebih efektif dengan orang tua dan anak, kekurangannya adalah pembelajaran ini dilakukan dalam waktu yang singkat dan guru harus mengunjungi kelompok belajar satu persatu.

\section{SIMPULAN DAN SARAN}

\section{A. Simpulan}

Pembelajaran home visitdi masa pandemi Covid-19 di SD Negeri 25 Woja. Sesuai dengan Surat Edara Bupati Dompu: Nomor 420/3320/.UM/Dikbud/ tanggal 22 Juli 2020 selama pandemi Covid-19 tentang izin penyelenggaraaan pembelajaraan tatap muka pada zona hijau dan kuning di masa pandemi Covid-19, Adapun dalam pelaksanaa pembelajaran home visit ada tiga tahapan yaitu: yaitu tahap persiapan pada tahap ini guru melakukan pembagian kelompok berdasarkan tempat tinggal, membuat jadwal kunjungan, Setelah melakukan persiapan, selanjutnya tahap pelaksanaan yang dibagi menjadi dua. Yaitu tahap pelaksanaan awal dan tahap pelaksanaan kegiatan lanjutan. Pada tahap pelaksanaan awal guru akan mengunjungi rumah kelompok belajar sesuai jadwal kunjungan yang telah ditetapkan. Guru mengunjungi dua kelompok dalam satu hari, kunjungan pertama dimulai pukul 08:00-09:30 dan kunjungan kedua dimulai pada 10:00-11:30 setiap kelompok belajar memperoleh kunjungan sebanyak dua kali dalam seminggu. Pada saat pelaksanaan home visit guru dan siswa harus menggunakan masker dan jaga jarak, pelaksanaanya dilaksanakan secara semi formal, dimana siswa tidak menggunakan seragam sekolah.

Setelah dilakukan kunjungan, tahap selanjutnya, adalah tahap pelaksanaan kegiatan lanjutan. Pada tahap ini guru memberikan tugas yang akan dikerjakan setelah memperoleh kunjungan.pada tahap ini, peserta didik belajar dengan bimbingan orang tua dan dievaluasi oleh guru. Guru akan memberikan arahan mengenai tugas yang harus dikerjakan oleh peserta didik dan guru akan memberikan pedoman berupa buku paket bagi orang tua dalam membimbing peserta didik mengerjakan tugas tersebut, Tahapan terakhir dalam pelaksanaan home visit adalah tahapan evaluasi pembelajaran. Pada tahap evaluasi guru akan meminta orang tua untuk mengontrol kegiatan anak belajar di rumah dalam mengerjakan tugas yang diberikan oleh guru. Tahap evaluasi dilakukan dengan mengoreksi tugas peserta didik untuk 
mengetahui apakah pembelajaran menggunakan home visit ini dapat mempermudah peserta didik memahami materi pembelajaran pada masa pandemi Covid-19 saat ini.

\section{B. Saran}

Dengan segala kekurangan dan keterbatasan, akhirnya penulis dapat menyelesaikan skripsi ini, oleh sebab itu penulis memberikan saran kepada beberapa pihak sekolah sebagai konsekuensi dari penelitian yang dilakukan: (1) Bagi Kepala Sekolah, Dapat dijadikan sebagai sumber referensi bagi sekolah SD Negeri 25 Woja, yang berkaitan dengan pembelajaran home visit sebagai alternatif di masa pandemi serta untuk mengoptimalkan proses belajar mengajar dengan memperhatikan situasi yang sedang berlangsung, (2) Bagi Guru Kelas, Agar dapat mempertahankan dan meningkatkan pelaksanaan pembelajaran menggunakan home visit ini demi mengoptimalkan proses belajar mengajar di masa pandemi Covid-19, (3) Bagi Siswa, Kepada siswa di SD Negeri 25 Woja, hendaknya lebih aktif dalam mengikuti proses pembelajaran home visit serta memperhatikan penjelasan guru kelas/guru pendamping yang sedang menyampaikan proses pembelajaran home visit di masa pandemi Covid-19 yang diterapkan dirumah atau halaman rumah supaya siswa mudah memahami penjelasan materi pelajaran yang sedang berlangsung, (4) Bagi Orang Tua, Peserta didik untuk terus ikut serta dalam membimbing anak-anak mereka untuk belajar dirumah demi mengoptimalkan penyampaian materi pembelajaran di mada pandemi Covid-19.

\section{DAFTAR RUJUKAN}

Ade Anggraeni. 2018. Pengaruh Home Visit Dan Motivasi Belajar Terhadap Hasil Belajar Siswa. Jurnal Ekonomi, Bisnis, dan Akutansi (JEBA): 20 (1): 2.

Ahmad Tanzeh 2011. Metodologi Penelitian Praktis. Jogjakarta: Teras.

Aisyah Nur. 2016. Faktor-Faktor Pendukung Dan Penghambat Home Visit. Skripsi, Banjarmasin: Universitas Institusi Agama Islam Negeri Antasari.

Alix Juhji. 2016. Peran Urgen Guru Dalam Pendidikan. Jurnal Ilmiah Pendidikan: 10 (1): 61.

Amalia Husna. 2016. Implementasi Home Visit Dalam Upaya Meningkatkan Pembelajaran. Jurnal Didaktika Amalia: 4 (1): 80-82.

Aziza Hestyana. 2013. Peran Guru Bimbingan Dan Konseling Dalam Pelaksanaan kegiatan Kunjungan Rumah. Jurnal Ilmiah Konseling: 2 (3): 16-20.

Azhar, Safuddin. (online), http://www.edukasiana.net/2012/2017/data-primer-dan-datasekunder.html/, diakses pada 17 September 2020.

Hendra. 2017. Sosok Guru Handal-Tangguh, Berkepribadian Selamat Dunia Akhirat. Skripsi, Malang: Universitas Islam Negeri Maulana Malik Ibrahim.

Heristaia. 2018. Guru Adalah Manajemen Sesungguhnya Di Sekolah. Jurnal Manajemen Pendidikan Islam: 1 (1): 120-121.

Idzhar Ahmad. 2016. Peranan Guru Dalam Meningkatkan Motivasi Belajar Siswa. Jurnal Office: 2 (2): 223.

Kuswarno, Engkus 2010. Metodologi Penelitian Komunikasi Fenomenologi; Konsepsi, Pedoman, dan Contoh Penelitian, Bandung: Widya Padjajaran.

Mafruri Muh. 2018. Dasar-Dasar Bimbingan Dan Konseling. Skripsi, Yogyakarta: Universitas Islam Negeri Sunan Kalijaga.

M. Shabiru. 2015. Kedudukan Guru Sebagai Pendidik. Jurnal Auladuna: 2 (2): 224.

Nahdi, K, Ramdhani, S, Yulianti, R,R dan Hadi, Y, A, 2020. Implementasi Pembelajaran Pada Masa Lockdown Babi Lembaga PAUD di Kabupaten Lombok Timur. Jurnal Obsesi : Jurnal 


Pendidikan Anak Usia Dini, Vol 5(1), 177-186.ISSN: 2549-
8959https://doi.org/10.31004/obsesi.v5il.529

Nirmala, B, dan Annur, H. 2021. Home Visit : Strategi PAUD Dari Rumah Bagi Guru di Daerah 3TPada Masa Pandemi Covid-19. 5(2), 1052-1062. https://doi.org/10.31004/obsesi.v5i2.716

Permendikbud Nomor 15 Tahun 2018 Tentang Pemenuhan Beban Kerja Guru, Kepala Sekolah, dan Pengawasan Sekolah.

Rachman, S. A. 2020. Pentingnya Penyediaan Lingkungan Belajar Yang Kondusif Bagi Anak Usia Dini Berbasis Kunjungan Belajar Di Masa New Normal. Jurnal Ilmiah Wahana Pendidikan, Vol 6(3), 480-487. e-ISSN: 2089-5364 p-ISSN: 2622-8327 https://doi.org/10.5281/zenodo.4035268

Rizma Ziah. 2016. Implementasi Manajemen Layanan Bimbingan Dan Konseling Di Sekolah Dan Madrasah. Jurnal Kependidikan Islam Al- Fikrah: 5 (3): 11.

Sa'diyah Halimah. 2015. Bimbingan dan konseling. Skripsi, Yogyakarta: Universitas Islam Negeri Sunan Kalijaga.

Sadikin, A. (2019) Pembelajaran Daring di Tengah Wabah Covid-19. TARBAWY: Indonesia Journal of Islamiac Education, Vol 6(2), 187-192. ISSN 2580-0922. https://doi.org/10.17509/t.v6i2.20887.

Sari, Siska M. Dkk. 2013. Hambatan Yang Dialami Guru dalam Pelaksanaan Kegiatan Kunjungan Rumah. Jurnal Ilmiah Konseling: 2 (1): 59.

Sugiyono.2018. Metode Penelitian Kuintitatif, Kualitatif dan R\&D. Bandung: Alfabeta.

Suhedro, E. 2020 Strategi Pembelajaran Anak Usia Dini di Masa Pandemi Covid-19. Jurnal Ilmiah Tumbuh Kembang Anak Usia Dini, vol 5(3), 133-140. ISSN: 24774715.https://doi.org/10.14421/jga.2020.53-05

Sukmadinata, Syaodah, Nana. 2010. Pendidikan Metode Penelitian. Bandung: Remaja Rosdakarya.

Sumiati. 2018. Peranan Guru Kelas Dalam Meningkatkan Motivasi Belajar Siswa. Jurnal Tarbawi: 3 (2): 148.

Suwardi Imam Wibowo. 2018. Hubungan Peran Guru Dalam Proses Pembelajaran Terhadap Prestasi Belajar Siswa. Jurnal Gentala Pendidikan Dasar: 3 (2): 184.

Yaqien, Nurul. 2010. Esensialitas home visit dalam pendidikan. Jurnal pendidikan dan pembelajaran dasar: 1 (1): 10. 